\title{
Quod fuimus, estis; quod sumus, vos eritis Dialektika identity, alterity, uznání a mezí principu
}

\author{
Břetislav Horyna \\ Univerzita Konštantína Filozofa Nitra, SK
}

HORYNA, B.: Quod fuimus, estis; quod sumus, vos eritis. The Dialectic of Identity, Alterity, Recognition and the Limits of Principle

Philosophica Critica, vol. 5, 2019, no. 2, ISSN 1339-8970, pp. 30-45

The study "Quod fuimus, estis; quod sumus, vos eritis. The Dialectic of Identity, Alterity, Recognition and the Limits of Principle" deals with a problem which has achieved significant attention from the scientific literature of today (psychology, social psychology, sociology), media, the public, but also of course philosophy and philosophical anthropology: on the question of a person's identity and self-identification. It provides a partial overview of the different approaches to identity from various fields and comes to terms with crucial issues of national and cultural identity in its critique. The author concludes the study with the statement that the problem of identity often tends to be overestimated for political rather than scientific and philosophical reasons, something which often descends into the legitimisation of nationalism.

Key words: Identity - Alterity - Performativity - Recognition Principle - Critical Reason - National and Cultural Identity Nationalism - Limits of Principle

\section{Úvod}

Nad vchody do krypt, katakomb či nekropolí lze často číst nápis, který jsem použil jako název tohoto článku, jehož předmětem je identita: „Co jste vy, byli jsme též my; co jsme my, budete i vy“. Údajný verš z arabské poezie 3. století je možná tím nejvýstižnějším, co se o identitě vůbec dá říci: popisuje jediný vztah plné identity, který ještě nikdo nikdy nezpochybnil. Jeho vyvracení, stejně jako potvrzení není účelem ani následujícího textu: obojí by bylo zbytečné. Beru ho pouze jako snad dost důrazné memento 
před principiálnostmi, které nahrazují rozum a kritické rozvažování. Nejzazší mezí veškeré principiálnosti je nerozum. Za ním následuje už jenom útlak, násilí, donucování, dehonestace a pohrdání, svár o vyvolenost, vykořistování člověka člověkem, sebeidentifikace s nadřazeností a panstvím. Vanitas vanitatum, ušklebují se lebky, čekající v kryptách.

\section{Princip individuace}

Moderna jako epocha, v které se uplatnil poosvícenský, tzn. kritický typ racionality, byla a je epochou emancipace. Svým způsobem znamená emancipace svobodu nebo osvobození - emancipace může být svobodou k něčemu jako osvobozením od něčeho. Pro modernu je typická emancipace ke svobodě být individualitou a k osvobození od tlaku na jednotný celospolečenský rámec orientace a vedení vlastního života. Reálnost této podvojné modernistické svobody má společného jmenovatele v základních principech praktické filosofie, které se všechny scházejí ve známém výroku I. Kanta: „Habe Muth dich deines eigenen Verstades zu bedienen“ (Kant 1784, 48). ${ }^{1}$

Užívání vlastního kritického rozumu je individuační faktor, od nějž se očekává nepodléhání vnějšímu tlaku, který na jednotlivce vyvíjejí nejrůznější subjekty a instituce. Zároveň je v konečném efektu socializačním faktorem, protože emancipovaná, svéprávná a kriticky myslící individua se mají sdružovat ve společnost autarkních jednotlivců řídících se mravním imperativem až do úrovně kosmopolitní lidské pospolitosti. Poosvícenská racionalita tak sleduje v ideální podobě emancipaci člověka k autonomnímu kritickému rozumu, který ho osvobodí pro život v zájmu nové společnosti individualizovaných osob. Na tomto povšechném obrázku sociální a antropologické změny v duchu „vývoje k lepšímu“ je osvícensky nový právě jen princip individuace. Budeme-li všichni autonomními individui, budeme pro sebe vzájemně rozeznatelní ve své neopakovatelné jedinečnosti, budeme se tak poznávat a respektovat a vytvářet veřejnosti

„Měj odvahu užívat vlastní rozum“. Teze k článku I. Kanta „Odpověd’ na otázku. Co je osvícenství?", jehož zjevná radikálnost je sama kontextuální. Vznikl jako reakce na článek berlínského faráře Johanna Friedricha Zöllnera „Ist es rathsam, das Ehebündniß nicht ferner durch die Religion zu sanciren?", který vyšel v Berlinische Monatsschrift o rok dřív. V jedné poznámce pod čarou položil autor víceméně řečnickou provokativní otázku, zda „toto“ (míněna byla možnost necírkevního uzavření manželství) má být osvícenství. Tím začala tzv. diskuse o osvícenství. Protože se Kant soustředil na svůj rozum a méně již na myšlení druhých, nepostřehl, že už v zářijovém čísle berlínského měsíčníku vydal Moses Mendelssohn svůj traktát „Über die Frage: was heißt aufklären?" Později prohlásil, že kdyby o tom věděl, svůj článek by nepublikoval a citovaný výrok interpretoval tak, že osvícení znamená přemýšlet o všem, co člověk dělá. S tím samozřejmě nelze než souhlasit. 
kosmopolitně komunikujících lidí. Pojítkem celé této představy je imaginace užívání vlastního rozumu.

Aby byla řeč o kritickém užití vlastního rozumu možná, musí být splněno několik podmínek, především stanovena věrohodná kritéria, podle nichž poznám, zda v daném okamžiku používám vlastní rozum. Když řekneme o nějakém člověku „on má vlastní rozum“, může to znamenat (nejen podle teorie řečových aktů) mnohé: má informace, které ostatní nemají; nemá informace, které ostatní mají; má špatné zkušenosti s radami druhých; nemá žádné zkušenosti s radami druhých; je to mimořádná osobnost, jejíž úsudek předčí soudy ostatních; je to nedovzdělaný ambiciózní hlupák, kterému je marné radit. Všechna tato určení ale ukazují, že „mít vlastní rozum“ je nepojmová metafora.

Nedomnívám se, že rozumová činnost, tj. myšlení, může být plně vlastní, tzn. nezávislá na myšlení jiných. Činností takových „cizích rozumů“ historicky vzniká sociální pamět', která je teprve prostředím, v kterém si individua vytvářejí své sociálně-ontologické vazby a učí se vyjádřit je společným srozumitelným jazykem. Předpoklad autonomního myšlení nepodléhajícího cizím vlivům a tlakům je nesplnitelný ve všech oblastech lidského poznání, ve vědách, ale speciálně rovněž ve filosofii: existuje nějaký způsob, jak by se dala pěstovat filosofie bez závislosti na celkové poznatkové souvislosti dějin filosofie? I nejkrajnější anarchista začíná tím, že odmítá začínat tím, co bylo počátečním $(\alpha \rho \chi \alpha)$ pro druhé; taková archai ale musí sdílet s druhými ve svém myšlení. Když píšeme odborný text, dáváme do něj poznámky pod čarou: tento zvyk, který vznikal z potřeby doložit vlastní vzdělanost a dosáhnout profesního uznání, slouží dnes nejvíc jako ochranný štít proti nařčení z plagiátorství. Zamýšlíme se ale nad tím, v kterém okamžiku psaní dokážeme přesně určit, kdo, jak a čím nás ovlivnil natolik, aby byl uveden v poznámce? Koho jsme si mohli dovolit zapomenout? U tvořivých lidí se čas od času probouzí pocit, že je přepadla originální myšlenka. Čím více ale mají zkušeností, tzn., čím více pozornosti věnovali cizímu myšlení, tím prozřetelnější je jejich nakládání s vlastní originalitou; z vlastní zkušenosti musím potvrdit, že se ještě nestalo, abych svou originální myšlenku dřív nebo později nenašel už zpracovanou někým jiným, obvykle podstatně lépe a často již také vyvrácenou.

Mít odvahu k vlastnímu rozumu neznamená, že budeme myslet nezávisle, svobodně, kreativně atd.; nanejvýš se tím říká, že budeme myslet kriticky o tom, co napadne nás a co napadá ty druhé, kteří našli místo v naší sociální paměti. Všechny tyto vztahy, emancipace od něčeho a k něčemu, svoboda, eliminace jedněch vlivů a připuštění jiných vlivů, nejrůznější formy závislostí nebo dokonce epigonství, kritika, metakritika, to vše vytváří osobní individualitu. Individualitě je vlastní individuálnost, která může 
být poznávacím znakem lidí. Podle individuálnosti, která se odráží ve stylu malby, poznáme malíře; často jen podle několika tónů opery poznáme, zda ji složil Janáček nebo Wagner; člověk s alespoň základním školením ve filosofii rozezná text Platónových dialogů nebo kritik I. Kanta. Schopnost být individualitou a projevovat se s typickou individuálností však není pouze věc umění nebo filosofie, nýbrž se objevuje vlastně u každé tvořivé lidské práce: zubní lékař pozná svou a cizí práci; nástrojáři poznali podle způsobu opracování, kdo a jak dělal určitý výrobek; obsluha telegrafických stanic poznala, s kým komunikuje, protože každý radista má svůj osobitý styl, svou individualitu. Př́klady by mohly pokračovat.

Zhruba od Francouzské revoluce se utvářela naše racionalita na principu individualizace. Tomu odpovídal také vývoj jak širších sociálních, tak užších osobních vztahů, které jsme dokázali jako moderním způsobem socializovaní Evropané zaujímat. Individuační princip není nijak ideální, ale zvyšuje srozumitelnost vzájemných vztahů a ta zase umožňovala základní životní a mravní orientaci v poměrně komplikovaných situacích. Když se individualizace rozvinula ve společensky uznávanou hodnotu, označovanou jako individualismus, začaly se také odhalovat její původně ne zcela zřetelné další rysy. Individualismu je vlastní izolovanost: jako vymezenost se individualita nutně dostává do stavu izolace, který není typický samotou lidí, ale jejich vzájemným opouštěním se. Čím víc se proti sobě vymezujeme, tím víc se opouštíme, což nemusí individuality chápat pouze negativně, i když přitom sledují strmý nárůst spotřeby antidepresiv. Izolace se snadno zaměňuje s nezávislostí, i když nezávislý člověk je nejvíc závislý na těch, od kterých chce být nezávislý: potřebuje druhé, ostatní, jiné, cizí, bez nichž by jeho domnělá nezávislost nebyla patrná. Podobné platí o opuštěném člověku: jako opouštěný je pasivním předmětem nakládání druhých lidí, kteří ho nechávají být - bez tohoto aktu ponechávání by nikdy nemohli dosáhnout stavu opuštěnosti; jako opouštějící je aktivně odkázaný na přítomnost druhých, které může ponechávat jedině tehdy, jsou-li nejprve př́tomni a naučí-li se od nich, co znamená opouštět, myslet, jednat, záviset, být individualitou, nebýt konformní, nesdružovat se, užívat vlastní rozum.

Pro všechno nezávislé užívání vlastního rozumu platí „až pak“: až poznám, kudy a proč vede cesta mezi závisením a nezávisením; individualitou a přináležitostí; osobností a osobou; mezi mým rozumem a rozumem jiných. Až pak, kdy si dokážu vysvětlit, co je racionální, můžu začít mluvit o iracionálním; k poznání nelogického musím vědět, co všechno je logické; k poznání amorálního morální; k poznání neidentického identické; a také, k poznání nekritického myšlením musím být schopen odlišit všechno, co spadá pod kritické myšlení. Právě odlišení a schopnost kriteriálně 
odlišovat obsahově určuje zmiňované „až pak“: nemá smysl říkat, co je vlastní rozum, co nezávislost, s níž rozum používám, a co individuálnost, kterou tím dosáhnu, když neumím odlišit tyto termíny a pojmy od všeho, čím nejsou. Naopak má smysl klást taková určení jako hypotézy, které se všestranně prověří, odzkouší a prohloubí, nebo zavrhnou.

Poosvícenský individuační princip přestal ale během pozdní moderny vyhovovat, snad kvůli vazbě na individualismus, v němž se začalo spatř́ovat zlo pozdního postindustriálního věku. Ani principy neplatí jinak, než v určitých mezích; padnou-li meze, padají také principy. V Evropě začala éra identity.

\section{Bud'me štastní - žijeme v éře identity}

Neumím uvést důvody, které vedly k tomu, že „identita“ začala mít tak náhle cenu jako sůl - totiž nad zlato. Není patrný ani přesný časový zlom obratu k identitě. Z frekvence termínu v časopiseckých studiích, odborné literatuře, ale zejména v reklamách všeho druhu a vnitro společenské propagandě se zdá, že nástup pokynu „bud' identický“ (rozuměj „postarej se sám o sebe") souvisel s atmosférou 90. let 20. století a s tvrdým počátečním hegemonialismem neoliberalismu. 0 možné souvislosti svědčí jeden důležitý rys: identita roku 2020 je prvořadě digitální identita každého z nás, a protože skutečnou měnou 21. století jsou informace, je digitální identita cosi jako číslo konta, přes které je s námi obchodováno - organizacemi a subjekty, které stojí za všemožnými Smartphony, Googly apod., jejichž nejokázalejšími počiny je vynalézání GDPR a dalších opatření na uklidnění našich rozjitřených digitálních identit. Možná ale byla invaze identity nezamýšlená a neočekávaná podobně, jako tomu v dějinách filosofie u mnoha různých pojmů: náhodně a vlastně v rozporu se svou koncepcí názoru použil I. Kant výraz „světový názor“ (Weltanschauung) (Kant 1790, §26) a nemohl tušit, že přijde doba, kdy světový názor budou mít všichni, někteří dokonce vědecký; jeden bývalý úředník ve Washington DC dostal za úkol vypracovat zprávu o současné světové situaci, z které vznikl článek a poté knížka - jmenoval se F. Fukuyama a kromě toho, že ve svém díle shrnul myšlenky A. Kojève, připojil k nim jako vlastní př́spěvek výraz „konec dějin“; už od 80. let žijeme v postmoderní době, protože J.-F. Lyotard byl předpisy nucen napsat závěrečnou zprávu ze svého pobytu v Kanadě a potřeboval do ní něco autenticky originálního; podobně se termín „multikulturalismus" sice objevil v odborné souvislosti (Forbes 1967), ale součástí našeho myšlení se stal $v$ důsledku oficiální politiky kanadské vlády vůči etnickým menšinám, která označila svůj program z r. 1971 slovem multiculturalism a inspirovala tím následně Austrálii a poté další země. 
Ze všech těchto umělých výrazů, které nemají historickou genezi, a tudíž nemohou mít ustálenou sémantiku, se stal společenskovědní problém. To, že se tak radikálně zproblematizovaly, je patrně důsledek dvou okolností: a) žádný obecně akceptovaný význam nemají, b) tím, že nic neznamenají, poskytují nemalé možnosti zhodnocení v disertačních a habilitačních spisech, $\mathrm{v}$ novinářských rubrikách, $\mathrm{v}$ televizních debatách: obecně řečeno, jsou to skvělé př́ležitosti k urychlení kariérního růstu. Domnívám se, že v tomto ohledu se od nich výraz „identita“ neliší.

Slovo identita se řadí do poměrně rozrostlé společnosti těch výrazů, kterým všichni rozumíme, dokud se nás někdo nezeptá, co znamenají. Jednu z nejstarších zkušeností zaznamenal v tomto ohledu Augustinus Aurelius se slovem „čas“ a od jeho doby k naší se věc pohnula tak, že nyní už čas častěji neexistuje, než existuje. Řekl bych, že tak - časem - dopadne také slovo identita. Etymologicky pochází výraz identita z latinského idem, týž, tentýž, totéž; když řeknu o nějakém člověku, že je stále týž, nebo o nějaké věci nebo situaci, že je tatáž, jako byla před určitou dobou, označuji souhrn určitých typických zvláštností entity, předmětu nebo objektu jako shodné s typickými zvláštnostmi jiné entity, předmětu nebo objektu. Tím je odliším od všech ostatních entit, předmětů nebo objektů, které disponují sobě vlastním souhrnem charakteristických zvláštností, a proto nejsou tytéž. Nejedná se o nic výjimečného, co by přesahovalo naši základní orientaci ve světě: řadíme podobné k podobnému a vytváříme velké celky, v kterých následně stále podrobněji a detailněji rozlišujeme. Tuto diferenciaci označujeme jako proces učení; když se učíme, rozeznáváme stále jemnější a detailnější shody a rozdílnosti v tom, co fakticky je. Každé učení a s ním také každé vědecké poznání předpokládá, že na jeho začátku stojí různě velký souhrn předmětů, objektů a jevů s určitými typickými zvláštnostmi, s charakteristikami, kvůli kterým je označujeme jako v sobě identické objekty.

Identita je termín, který si pro sebe nárokuje několik oborů lidského poznání. Oborové rozčlenění při aplikaci pojmu identity může v hrubém nárysu vypadat následovně:
1. aristotelská zásada identity
2. matematické pojetí identity
3. psychologické určení identity
4. sociologické (kulturologické) a politologické chápání identity
5. identita v praktické filosofii, tzn. vztah etiky a identity

ad 1) Ve filosofii se termín identita frekventuje v podobě „zásady myšlení" nejpozději od Aristotela (1. zásada sporu: To, co je, nemůže zároveň nebýt; 2 . zásada identity: $\mathrm{A}=\mathrm{A}$; 3 . zásada vyloučení třetího: mezi bytím 
a nebytím téže věcné souvislosti není nic třetího; 4. zásada dostatečného důvodu). Zásada identity a zásada vyloučeného třetího se jeví vědecky a důvodem jejich vědeckosti je argumentum ad verecundiam: řekl to přece Aristoteles, takže př́liš neuvažujeme o tom, jak by se tyto zásady obhajovaly v kulturách s jiným typem racionality, než je ta naše. Stejně tak se neprověřuje, jak se osvědčí při přechodu kupříkladu na rovinu fyziky elementárních částic, do prostředí fyzikálních principů mikrosvěta. Kvantová mechanika se vymyká koridorům aristotelské a tomášovské rozumovosti a jeví se nesrozumitelně mj. proto, že po nás vyžaduje zapomenout zvyky, které ne zcela zdůvodněně považujeme za vědecké zásady. Některá pravidla, která určují, jak vypadá náš svět a čím se řídí, platí pouze v částicové fyzice a nemají analogii v makrosvětě. Nemáme s nimi přímou zkušenost, vymykají se naší představivosti, nejsme s to je konfrontovat s tradičními filosofickými pojmy, takže jako „poznání“ uznáváme Aristotelovu větu identity, i když tvrdit, že $\mathrm{A}$ = A a nikdy jinak je na úrovni poznání kvantové mechaniky nebo dokonce dynamiky už jen směšné.

Zásada identity se rozkolísá již při pouhém určení elektronu jako elektronu. Podle A = A platí El = El, jenže u elektronu nelze současně, v tentýž okamžik, poznat jeho hybnost a jeho polohu: bud' známe hybnost, nebo víme, kde „je“, ale obě souřadnice, které by nám dovolily mluvit o identitě elektronu, neznáme. Dobře známý je př́íklad s chováním elektronu při nárazu do překážky. $\mathrm{V}$ okamžiku nárazu závisí stav elektronu na relaci neurčitosti, která říká, že hybnost částice nemůže být nulová, ale musí být jiná než nulová: jaká je, je pro nás právě neurčité. Důležité je, že díky nenulové hybnosti se elektron nárazem na překážku nezastaví, ale proráží ji dál, a to i tehdy, když nemá dostatečnou energii, aby v překážce neuvízl. Podle téhož principu neurčitosti je totiž pravděpodobnost nalezení daného elektronu mimo překážku rovněž nenulová. Otázka zní, jak částice s nedostatkem energie překoná překážku svého pohybu. Ukazuje to zase rovnice druhého řádu z principu neurčitosti, jejíž výsledek říká, že současně s tím, jak elektron „proráží“ pevnou překážku, ji zároveň jakoby „obtéká“ a nachází se přitom ve stavu, který se dá popsat pouze jako vlnová funkce. Místo očekávaného $\mathrm{A}$ = A nastupuje El = současně Elsubstance + Elvlnění, ačkoli běží stále o tutéž částici.

Z toho lze odvodit první dílčí závěr: z logického ani z fyzikálního chápání identity nevede žádný stabilní přechod k filosofii.

ad 2) Podobně dlouhou tradici má termín identity v matematice, kde se objevuje jako prostá numerická identita, nebo jako relace mezi dvěma danými veličinami, nebo - nejtradičněji - jako tzv. Eulerova rovnost (identita). Eulerova rovnost je základní vzorec komplexní analýzy, což je obor 
matematické analýzy, který zkoumá funkce komplexních čísel. Eulerova rovnost je vzorec $\mathrm{e}^{\mathrm{\pi i}}+1=0$, kde e je Eulerovo číslo, i je imaginární jednot$\mathrm{ka}, \pi$ je Ludolfovo číslo.

Eulerova rovnost dává do souvislosti tři základní aritmetické operace (součet, součin a mocninu) s pěti základními analytickými konstantami $(\mathrm{e}, \mathrm{i}, \pi, 0,1)$. Přitom se $\mathrm{v}$ této rovnosti vyskytuje každá z operací a každá z konstant právě jednou a žádné jiné operace ani konstanty se v ní nevyskytují. Eulerova rovnost je speciálním př́ípadem obecnější identity, která ř́ká, že součet všech n-tých odmocnin z jedné je nulový pro $\mathrm{n}>1$. Pro matematiky je Eulerova rovnost krásná nebo elegantní, pro filosofii ale umožňuje pouze jeden závěr: matematická identita nemá ve filosofii nosné uplatnění.

ad 3) Psychologie a sociální psychologie zkoumají identitu jako relaci mezi dvěma a více danými veličinami, které jsou relevantní pro přijetí (inkluzi) nebo vyloučení (exkluzi) individua ze skupiny. Protože jsem nenašel komplexní souhrn a vysvětlení těchto pro psychologii relevantních veličin, pokoušel jsem se o vlastní základní přehled: výsledek je zvláštní a pro psychologii poměrně typický. Nejobecnější význam, který se slovu identita v psychologii dává, je zřejmě „sebeuvědomění člověka“, které se projevuje ve dvou relacích, a to k sobě jako subjektu sebeuvědomění a k ostatním členům společenství jako sociálně-psychologickému uskutečnění subjektivního sebeuvědomění. Následně jsem zjištoval, jaké zpřesňující charakteristiky se vztahují k tomuto základnímu významu: našel jsem 62 termínů, z nich se 32 týkalo sexuální identity, 9 termínů bylo z oblasti kulturní a sociální identity, a zbytek měl konotaci s klinickou psychologií a psychiatrií a částečně s antropologií. Nikde jsem nenašel clare et distincte určení toho, co identita je. Právě naopak, čím novější datum nesou práce o identitě, tím častěji se objevuje klasická lest rozumu: když nevím, o čem mluvím, uvedu hned na začátku, že není nutné vědět, o čem mluvím, abych o tom mluvit mohl. Téměř doslovně uvedl tento vědecký princip německý sociolog Peter Wagner ve svém značně kritickém článku o hledačích identity a jejich prostředcích: „... již je možné mluvit o identitě a neuvést, co je identické s čím“2 (Assmann 1998, 47). Možné je to proto, že se identita pojme jako empirický předmět výzkumu. Tím se problém přesune od definičního určování identity k procesu personální a sociální konstrukce identity. V konstruování identity spočívá dnes těžiště psychologických, sociologických a politologických koncepcí identity: jinými slovy, neumíme říci, co identita je, ale zato přesně popíšeme, jak vzniká a co způsobuje.

$2 \quad$ „.. es ist möglich geworden, über Identität zu sprechen, ohne anzugeben, was mit was identisch ist" (Assmann 1998, 47). 
$\mathrm{Z}$ mého hlediska neřešitelná antinomie $\mathrm{v}$ teorii identity jako procesu konstrukce spočívá $v$ tom, že individuum, které není původně nositelem identity, ji během nějak určeného procesu tvorby nebo osvojování získává. To znamená dvojí: připouští se, že osoby nejsou původními nositeli své identity, ale mohou se s něčím identifikovat; a to, s čím se mohou identifikovat, se nachází někde mimo ně, vykazuje jakousi samostatnou existenci, „někde je“. Řečeno obrazněji, identita je původně nezávisle na jednotlivci a čeká, až ten si pro ni přijde, dotvoří ji a osvojí si ji. Nutně vyvstává otázka: Kde je sklad identit? Mají identity inventární čísla? Je někde uložená specifická identita pro jednoho každého z nás? A hlavně: kdo je skladník? Kdo a s jakou kompetencí může určovat, zda to, co si osoba osvojí, je její identita, když k tomu nemáme žádná kritéria (nevíme, co identita je, a proto na tento poznatek rezignujeme)?

Odpovědi čekáme od psychologie: je identita původně něco, co může být bez nositelů identity? Kdo je nositelem identity? Individuum, dítě, psychicky nemocný člověk, národ, obyvatelstvo uměle vytvořeného státu bez společných dějin, tzn. bez kulturní paměti, jako je většina států vyrobených v průběhu kolonizace světa Evropou? Vysoce postavený politik, ředitel představenstva transnacionální finanční korporace, mad’arský taxikář v Nitře, operní sólista, umělec, který zpívá na všech možných scénách, kromě těch českých nebo slovenských? Kdokoli z nich by upadl do rukou prazvláštních mladých mužů a žen, kteří se dnes sami označují titulem „kouč/koučka“, vyslechl by neocenitelnou radu „,bud' sám/a sebou“, „najdi sebe sama“, „najdi svou identitu a nauč se přijmout sebe sama“.

Kdyby da Vinci, van Gogh, Gustav Mahler, Karl Marx nebo Albert Einstein poslouchali tyhle učenosti a smírně by „přijali sebe sama“, byla by množina faktorů, která nám umožňuje konsensuálně uvažovat o národní nebo kulturní identitě, podstatně chudší. Před nedávnem zemřel Stephen Hawking, který měl jediné štěstí (a s ním také naše poznání vesmíru), že nepřijal sám sebe. Kdyby to udělal, zemřel by podle lékařských prognóz již roku 1964, možná na otravu alkoholem. Zdá se, že rady typu „bud’ sám sebou“, „bud' chodící sebeidentita“ jsou kontraproduktivní. Nejen že patří k tomu nejhloupějšímu, co lze druhému člověku naordinovat ${ }^{3}$, ale navíc představují zřetelné riziko kulturních ztrát a ochuzení.

ad 4) Na sociologické (kulturologické) a obecně sociálněvědné rovině se kumulují problémy, svázané s pojmem identita. $\mathrm{V}$ perspektivě těchto věd se identita ocitá v kontrární pozici vůči pojmu socializace, a pak je otázka, zda identita znamená autonomii vůči rámci socializace, nebo naopak

3 V tomto smyslu nejvyšší a zcela nedostižnou mírou hlouposti disponuje pokyn „poznej sám sebe“. 
je identita výsledkem determinace osoby kontextem socializace. V prvním př́padě se slovem identita určuje vlastně jen míra distance individua od sociálního, kulturního, politického nebo náboženského prostředí, v kterém se původně nacházel: identita by jen ukazovala stupeň individuálního nonkonformismu. Naopak druhý případ znamená míru ztotožnění s nějakou skupinou nebo kolektivem lidí, s nimiž daná osoba sdílí postoje osvojené při socializaci: může jít o malé např. zájmové skupiny (dílčí veřejnosti se specifickými diskurzy), ale stejně tak o národy, etnika nebo jiná velká společenství. $V$ obou př́padech identita vypovídá o stabilitě postavení člověka v životě, o stabilitě jeho obrazu světa a svým způsobem také o spolehlivosti našeho vědění o světě.

Platí zde dvě nepř́mé úměry. První ukazuje, že čím je obraz světa jednotlivců nebo skupin stabilnější (nezpochybňovaný, nekritizovaný, obecně přijímaný, je základem vzdělávání, atd.) tím je potřeba ubezpečovat se vlastní identitou nižší; prŕíkladem může být třeba islám, kde je potřeba zajištování se nějakou zkonstruovanou identitou tak nízká, že nerozvinul ani teologii. Druhá úměra se týká toho, že čím nižší je míra znalostí o světě, tím je obraz světa a s ním pocit identity pevnější. Nevzdělaný člověk je mocensko-politická cenina: nikdo další se nebude tak identifikovat s určitým přesvědčením jako on, zvlášt' když se podaří vtisknout mu je tak, aby si myslel, že je to jeho vlastní názor a jeho svoboda.

Nejsilněji se v sociálních vědách spojuje kategorie identity s kategorií národa. Jde o značně komplikovanou vazbu, protože se přiřazují dva termíny s nejasným významem a velmi snad no instrumentalizovaným výkladem, a nadto vzniká silně emocionální pole, které je zatížené historickými a ohrožené budoucími konflikty. Za předpokladu, že každé lidské individuum vlastní nějakou identitu, nezávisle na individuálních předpokladech a možnostech sebereflexe, je ztotožnění s národem nejvýhodnější řešení. Nevyžaduje, aby osoba odvedla typický individuační výkon, podle kterého ji identifikujeme, nemusí dokonce vykonat vůbec nic, a přesto bude svým okolím uznána za „člověka s identitou“: stačí se jen přidat k ostatním, což může být čistě verbální akt, kterému nemusí odpovídat žádná realita. Prožívání identity se tím usnadňuje až po meze absurdnosti; osoba získává status, může svou národní identitu ztotožnit s hodnotou svého života, a přitom ani nepostřehnout, že disponuje jen něčím předepsaným a od ní odcizeným.

Jisté je, že návrat problému identity se časově shoduje s oživením nacionalismu v Evropě a v EU. Se zesílením zájmu o roli a pravomoci národních států se objevila identita jako nástroj, který má postavení národních států zdůvodňovat a garantovat. Lze jistě uvažovat o tom, zda silná životaschopnost nacionalismu není důsledkem sepětí národní a etnické 
identity. „Národ“ je pro mnoho lidí významná kategorie; právě to by mělo přimět stoupence národní identity, aby národ stavěli na něčem méně intuitivním, méně emocionálním a fakticky určitějším než je současný pojem identity, naplněný nejvíc ze všeho sémantickou libovůlí. Národ je velká sociální skupina rovnoprávných občanů se státní příslušností, která trvá i tehdy, je-li překonán nebo odstraněn nacionalismus. Dál žije představa národního zájmu, stmelující funkce jazyka a národní identita si ponechává dominantní postavení mezi ostatními způsoby sebeidentifikace. Nacionalismus tudíž není pro uchování národní identity nejen nezbytný, ale ani potřebný, přesto se $s$ jeho znaky setkáváme mimořádně často. To mělo objektivní důvody: nová národní identita vznikala za historických, hospodářských, politických, etnických, administrativních a dalších podmínek, které zformovaly národní pospolitost. Tytéž podmínky vytvářely tlak na jednotlivce, aby na sebe bral závazek sloužit svému národu, a tím se vytvářel socializační a pedagogický rámec, v němž se takový závazek stal „mravní povinností“ se silně disciplinačním účinkem.

Úspěch symbiózy nacionalismu s národní identitou shrnul do šesti přehledných bodů český historik M. Hroch (BOER, P. den 2012, 75-98): a) každá národní identita je spojena s vymezením se vůči „jiným“, resp. cizím; s tím, jak se toto vymezení potencovalo do domnělého nebo skutečného ohrožení (,jiný“ = nepř́ítel), vyhrocovala se rovněž tendence k nacionalismu; b) zásadní faktor nacionální agitace tvoří sociální komunikace zaměřená na šíření a prohlubování národní identity; ideální podmínky má ve státech s relativně vysokým školním vzděláním, s tržními vztahy a vysokou sociální mobilitou; c) moderní národy vznikaly sociální emancipací do té doby podrobeného obyvatelstva (zrušení feudálních vazeb); existenčně závisí na myšlence občanské rovnosti, kterou realizuje národ, jenž se tak stává hodnotou „o sobě“; d) velkou roli hrají etnické kořeny, které ale u většiny národů splývají s jazykovou homogenitou; mít svůj jazyk bylo cílem všech moderních národních obrození 18. / 19. století; e) etnické vazby, tzn., zejm. jazyk národa, mají nesmírně silný emoční potenciál, který nelze nahradit žádným společným jazykem, žádnou lingua franca; f) národní identita v Evropě 19. století, z které rostl nacionalismus, byla vždy historická; př́slušníci národa se vždy chápou v návaznosti na činy svých předků, jako nositelé odkazu, který jsou povinni obohatit a předat svým potomkům.

V roce 2017 vydal francouzský politický filosof François Jullien pod názvem „Kulturní identita neexistuje“ polemiku, kterou představil jako pokus o obranu zdrojů evropských kultur před zničením v nacionalistických svárech (Jullien 2017). Položil si otázku, jak je možné mluvit o národní nebo kulturní identitě jako něčem pevném a stabilním, když všechno, co si 
dokážeme představit jako součást takové identity, je proměnlivé a nestálé. V kterém okamžiku takové proměnlivosti by se pak měla zachytit „identita kultury"? V kterém století nebo desetiletí, v které válce nebo revoluci? Když uvážíme skutečnost, kterou M. Hroch zmiňuje pod bodem f) a která hraje patrně jednu z nejsilnějších rolí při utváření nacionalismu („otec zanechal mně, já musím zanechat synovi“), pak je zřejmé, že toto myšlení vyžaduje silný redukcionismus. Ne ke každému dědictví se člověk může a má hlásit s tím, že utvrzuje jeho identitu a musí je uchránit pro budoucí; své o tom ví Německo a stranou by nemuseli zůstávat ani jeho váleční spojenci. Hrdinství jedněch nepřekrývá nikdy selhání nebo přímo zločiny druhých a často ani zásadní zobecnění vedoucí až k neurčitosti a extrémně selektivní historická pamět' nemohou zakrýt, že národní a kulturní identita založená na redukcionismu je vyumělkovaná konstrukce.

Redukcionismus je postoj, který dovoluje jen některé otázky ze spektra možných a má k nim prefabrikované odpovědi. Redukcionismus nejprve vyžaduje a následně legitimizuje předsudky, které máme vůči sobě a jiným. Není celý nacionalismus s národní identitou jen jeden velký předsudek - jak o sobě, tak o druhých? Nevím, zda předsudek je správné slovo, ale mám za jisté, že nacionalismus je společensky uznávaná forma civilizovaného pohrdání.

ad 5) Problém postavení identity v praktické filosofii klade otázku po souvislosti identity s problémem hodnot: Je identita hodnota? Člověk by měl být schopen říct, na co se ptá, tzn., co se chce dozvědět. Filosof se tradičně vymezuje jako ten, kdo se nenechá odlákat nedůležitými otázkami. Filosofie možná vyniká v mnoha ohledech, ale v jednom je skutečně mistrná: je to schopnost klást úplně scestné otázky. Jsou to ty otázky, které nikdo neklade a tudíž nikdo ani neočekává nějaké odpovědi; otázky, které občas vzbuzují chut’ definovat filosofii jako deviaci otazníku.

Otázka, zda je identita hodnota, má k tomu druhu ptaní docela blízko. Ptáme se, zda něco, co nedokážeme uspokojivě faktuálně specifikovat a musíme se spoléhat na fikční určení, je nebo není ontologicky identitní s něčím jiným, co také nedokážeme uspokojivě faktuálně specifikovat. Protože otázku „co je hodnota“ musí předcházet ještě jiný problém: jsou hodnoty? Fakt, že se ve filosofii mluví o hodnotách po tisíciletí, nesouvisí s odpovědí na otázku, zda a co jsou: filosofie už mluvila o mnoha věcech. Když se osoba snaží vymezit svou identitu, vede nejprve něco jako vnitřní rozhovor sama se sebou, v kterém bud' předpokládá, že jako osoba má hodnotu, nebo že být osoba s definovatelnou identitou znamená mít hodnotu. Co ale znamená tohle „mít hodnotu“? 
Během vyhlazovacích akcí za 2 . sv. války vypočetli nacističtí statistikové, že hodnota zplynovaného jedince po zpracování všeho, co se dalo zpracovat, je 800 říšských marek. To byla užitná hodnota zavražděného člověka. Nejvyšší ćástka, která byla zaplacena za přestup fotbalisty z klubu do jiného klubu ${ }^{4}$ je 222 miliónů €: to je tržní hodnota člověka, jehož identita spočívá ve schopnosti kopat do míče. Německý publicista F. H. Sauer vydal r. 2019 encyklopedii nazvanou Velká kniha hodnot 2019, která obsahuje výčet 123 pojmů označených jako hodnoty (Wertebegriffe). V knize je zmiňován humor, aktivita, neutralita, nezávislost, tolerance, moudrost, cílevědomost, ale také preciznost, flexibilita, komfort, pohodlnost nebo disciplína. Několikrát se vyskytují pojmy, které chápeme spíš jako antonyma: např. Gelassenheit (uvolněnost, pohodářství, neulpívání; ve starohornoněmčině „boží dopuštění“), vedle níž stojí Tüchtigkeit (důkladnost, zdatnost), Ordnungssinn (pořádkumilovnost, smysl pro řád), Pünktlichkeit (přesnost, puntičkářství). Samostatnou hodnotou jsou idealismus, realismus a s ním spiritualita. V zásadě nemám nic proti, spíš v tom vidím doklad přesvědčení, že hodnotou je bílá stejně jako černá, tzn., cokoli, o čem řekneme, že to $v$ našem předem přijatém významovém kontextu má „smysl hodnoty“.

Tím se vracím k otázce, zda hodnoty jsou. První dva př́́klady se z debaty vylučují: užitná hodnota, nadhodnota, tržní hodnota, cena, sice něco označují, ale ve své vlastní souvislosti (zejména ekonomické). Citovaná encyklopedie hodnot neuvádí hodnoty, ale vlastnosti nebo charakteristiky věcí, osob a druhů jednání, které v dané situaci, $\mathrm{v}$ daném čase a v daném kontextu prostě preferujeme. Při změně kontextu se změní preference a místo flexibility před námi najednou vyvstává přizpůsobivost, oportunismus. Staré pyrrhónské trópy uváděly př́klady věcí, které pro jednoho představovaly klad, pro druhého zápor, pro jednoho bolest, pro druhého radost, pro jednoho život, pro druhého smrt. Pro rozhodnutí a př́íklon $\mathrm{k}$ jednomu konkrétnímu významu dané věci, o které by se pak dalo říci „toto je hodnota“, nemáme kritéria, a ani plně neznáme možnosti, v kterých se daná věc může objevit (omezující role neúplné indukce, která se v hodnotových soudech obvykle nezmiňuje).

Taková rozhodnutí jsou záležitost přesvědčení, víry, málokdy názoru: nejsou součástí vědomostí, poznání a vědění. Nejhorší mor člověka je jeho přesvědčení, že ví, říká jedna teze francouzského skeptika Michela de Montaigne: lidé vraždili a stále vraždí ne kvůli poznání, ale kvůli domněnce, že vědí, co jsou správné a pravdivé hodnoty. Na otázku, zda hodnoty jsou vůbec, příp. jak je možná hodnota ve své jsoucnosti, se odpovídá

4 Jednalo se o přestup hráče Neymara v Barcelony do Paříže v r. 2017. 
zesměšněním tazatele, zpravidla z pozice morální (obvykle náboženské) nadřazenosti. Já jsem identický se svým národem, národní identita je tudíž hodnota, protože národ je hodnota: dobře, ale jak to můžu poznat? Tomu se dá pouze věřit, tzn., může to být něco důležitého z hlediska individuální psychiky a sociální psychologie; pokud by to měla být hodnota s nějakým objektovým určením, musela by být jako taková rozpoznatelná kýmkoli a kdykoli. Což prokazatelně není.

Jisté komplikace s národní a etnickou identitou naznačují také moderní vědecké výzkumy. Na Masarykově univerzitě v Brně proběhl v r. 2017 výzkum genetické informace obyvatel Čech a Moravy: ukázalo se, že $18 \%$ dnešního obyvatelstva pochází z původního pravěkého obyvatelstva Evropy, z lovců mamutů, a ti jsou jako jediní v Česku skutečně doma; ostatní jsou imigranti, a to 30 \% Slovanů, 35 \% Keltogermánů, a zbývající genetický mix, v kterém jsou Albánci, Gruzíni, národy ze severní Afriky ad. Tím nespojuji národnostní identifikaci s genetikou, což by bylo nesmyslné, protože žádný úsek DNA se nevyskytuje jen u jednoho národa. Chci pouze upozornit, že nejrůznější tradice, kterým se přisuzuje vlastnost „hodnoty“, se nemusí zakládat na ničem reálném a jsou jen výsledkem emocí a imaginací.

\section{Závěr}

Hodnoty jistě jsou, protože jsou naše hodnotové soudy, které přisuzují určitý hodnotový význam různým jevům (zejména těm, které plynou z lidské činnosti) a různým pojmům, které tyto jevy zachycují. Proto si nemyslím, že jsou nějaké všeobecně platné, univerzální všelidské hodnoty (tak jako nejsou ani univerzální lidská práva). K tomu by byla nutná shoda všech aktuálně žijících lidí na této planetě.

Zdá se, že k problému hodnot a identit neumím říct nic, co by bylo možné verifikovat pomocí vědeckých prostředků, z čeho by bylo možné vytvořit argument, který by odolal vědecké zpětné rekonstrukci a ověření. Přes to všechno zastávám určité postoje a při výkladu světa mám určité preference. Je tomu tak proto, že identita je myslitelná jako modus sociální zkušenosti, analogicky tomu, jak můžeme myslet alteritu, image, autenticitu, radikálnost, anarchismus, konformismus, atd.

Mé postoje odpovídají mé sociální zkušenosti, která vzniká z bezpočtu vlivů, které nikdo není schopen ani vyjmenovat, natož pak vyhodnotit, a z jejich čistě individuálního rozumového zpracování, které se odehrává opět pod bezpočtem na mě působících vlivů, a tak stále dokola in infinitum, tzn. k momentu, kdy jsme nuceni naše poznání axiomatizovat, abychom vůbec měli odkud začít. Když tím axiomem bude teze o identitě 
a hodnotách, nic se nestane a budu to akceptovat stejně, jako akceptuji fakt, že celé naše poznání je a musí být axiomatizované. Když se ale identity a hodnoty změní v důvod, proč škodit druhým lidem nebo je dokonce ohrožovat na životě, začnu hájit hodnotu likvidace všech, kteří zabíjejí ve jménu hodnot.

\section{Literatúra}

ABELS, H. (2006): Identität. Über die Entstehung des Gedankens, dass der Mensch ein Individuum ist, den nicht leicht zu verwirklichenden Anspruch auf Individualität und die Tatsache, dass Identität in Zeiten der Individualisierung von der Hand in den Mund lebt. Wiesbaden: VS, Verlag für Sozialwissenschaften.

ASSMANN, A./ FRIESE, H. (1998): Identitäten. (Erinnerung, Geschichte, Identität). Frankfurt a. M.: Suhrkamp Verlag.

BOER, P. den et al. (2012): Europäische Erinnerungsorte 1., Mythen und Grundbegriffe des europäischen Selbstverständnisses, 2. Das Haus Europa, 3. Europa und die Welt. München: Oldenbourg

BĚLOHRAD, R. (2019): On Three Attempts to Rebut the Evans Argument against Indeterminate Identity. In: Croatian Journal of Philosophy, Zagreb: Institute of Philosophy, 19 (55), 137-152.

BĚLOHRAD, R. (2019): Constitution, Vague Objects and Persistence. In: Prolegomena, Zagreb: Society for the Advancement of Philosophy, 18 (1), 5-26. BĚLOHRAD, R. (2016): Lidské identity, lidské hodnoty. Praha, Dybbuk.

BĚLOHRAD, R. - JASTRZEMBSKÁ, Z. (2013): O aplikaci metod vědeckého zdůvodnění a vysvětlení v etice. In: Organon F: filozofický časopis, Bratislava: Filozofický ústav SAV, 20 (Supplementary Issue 1), 5-23.

DÜLMEN, R. van (ed.) (2001): Entdeckung des Ich: Die Geschichte der Individualisierung vom Mittelalter bis zur Gegenwart. Köln: Böhlau.

FORBES, J. D. (1967): The Education of the Culturally Different. A Multicultural Approach. Berkeley: Fat West Laboratory for Educational Research and Development.

JASTRZEMBSKÁ, Z. (2009): Aspekty vysvětlení: hledání explanačních znalostí. Olomouc: Nakladatelství Olomouc

JASTRZEMBSKÁ, Z. (2004): Proč vysvětlení není argument. In: Pro-fil. Elektronický časopis pro filozofii. Brno: Katedra filosofie FF MU, 5 (1), 1-8.

JULLIEN, F. (2017): Es gibt keine kulturelle Identität. Berlin: Suhrkamp.

KANT, I. (1784): Beantwortung der Frage: Was ist Aufklärung? In: Berlinische Monatsschrift, H. 12, 481 - 494.

KANT, I. (1983): Kritik der Urteilskraft, Werke in sechs Bänden, Band 5. Darmstadt: Wissenschaftliche Buchgesellschaft.

KEUPP, H. u. a. (1999): Identitätskonstruktionen. Das Patchwork der Identitäten in der Spätmoderne. Reinbek bei Hamburg: Rowohlt.

MARQUARD, O. - STIERLE, K.-H. (eds.) (1979): Identität. (Poetik und Hermeneutik VIII). München. Fink. 
SAUER, F. H. (2019): Das große Buch der Werte 2019: Enzyklopädie der Wertvorstellungen. Frankfurt a. M.: INTUISTIK-Verlag.

Štúdia vznikla s podporou grantu VEGA č. 1/0291/18 Historickofilozofická analýza environmentálneho myslenia, skúmanie jeho vplyvov na etické, právne a politické myslenie a jeho spoločenská odozva.

Prof. PhDr. Břetislav Horyna, PhD.

Katedra filozofie FF UKF Nitra

Hodžova 1

94974 Nitra

bhoryna@ukf.sk

orcid.org/0000-0002-6610-246X 